\section{DIGITAL COMMONS \\ @ UNIVERSITY OF SOUTH FLORIDA}

\section{ABO: Interactive Journal for Women in the Arts, 1640-1830}

Volume 11

Issue 1 Summer 2021

Article 15

2021

\title{
Covid Diary: Scholarship and Gardening
}

Jessica Munns

University of Denver, munns.jessica@gmail.com

Follow this and additional works at: https://digitalcommons.usf.edu/abo

Part of the Dramatic Literature, Criticism and Theory Commons, Educational Methods Commons, Feminist, Gender, and Sexuality Studies Commons, and the Literature in English, British Isles Commons

\section{Recommended Citation}

Munns, Jessica (2021) "Covid Diary: Scholarship and Gardening," ABO: Interactive Journal for Women in the Arts, 1640-1830: Vol.11: Iss.1, Article 15.

http://doi.org/10.5038/2157-7129.11.1.1258

Available at: https://digitalcommons.usf.edu/abo/vol11/iss1/15

This Conversation is brought to you for free and open access by Digital Commons @ University of South Florida. It has been accepted for inclusion in ABO: Interactive Journal for Women in the Arts, 1640-1830 by an authorized administrator of Digital Commons @ University of South Florida. For more information, please contact digitalcommons@usf.edu. 
Covid Diary: Scholarship and Gardening

\section{Keywords}

Diary, writing, scholarship

Creative Commons License

(c) (i) (9)

This work is licensed under a Creative Commons Attribution-Noncommercial 4.0 License 


\section{Diary: Scholarship, laundry, cooking, gardening and writing.}

\section{A Week in the Plague Year. February, 2021}

Monday: Every two weeks Monday evening is French Night. In the old preCovid and serial lockdowns days, my sister Penny and I would meet up with other members of our Cercle Français for an evening of talking in French and listening to a conférence in French. Not gathering, meeting friends and actually relations, our cousin whose elegantly inflected and fluent French is a source of admiration and envy, has been one of those things we really miss. Now, thanks to Zoom we can meet virtually, and tonight Thierry Vienois, a speaker provided by the Alliance Française as part of their cultural mission to our barbaric Brexit Isle, will be talking about Tintin, the famous and nowadays politically dubious creation of Belgian cartoonist Hergé. On the Mondays when there is no Zoom meeting, we watch a French film, for weeks now Le Bureau whose characters incidentally have nicknames taken from Tintin. More fun than Le Bureau is Dix Pour Cent (Call My Agent), a witty take on a show biz agency with real life stars, Juliette Binoche, Natalie Baye and Cécile de France taking part in a good natured and low- key way. We also watch Engrenages (Spiral) which has done great things for our colloquial French. We now know a car is not ever une voiture if you are cool but une bagnole and a job is un bouleau. We have learnt a lot of new swear words too!

Tuesday: My sister and I have been editing a Restoration tragedy as our at home project this year. This would have been totally impossible without access to EEBO (Early English Books Online) and ECCO (Eighteenth-Century Catalogue Online) and the London Library. Membership of the London Library has been my retirement present to myself - and as I am now unable to reach a university library what a gift it has been. Established in 1841 on the urging and with the support of Thomas Carlyle, it is located in St. James Square, London, and is a wonderful place to visit. It has a cataloguing and stacking system all of its own and finding a book often means clambering across swaying gantries and up ancient spiral staircases. Sadly the building is closed while we are in lockdown, but the London Library has always also operated as a postal library, and readers are allowed a large number of books for long loan periods.

It's Shrove Tuesday, Pancake Day as we say in the UK, so we'll have jam pancakes for dessert tonight.

Wednesday: On Wednesday we have a delivery of organic fruit and vegetables from a farm in Devon. Getting onto their delivery list has been one of our Covid 
coups. Mid-week, and so far no work on our play! It is difficult to self-motivate, no matter how deeply the work in hand fascinates. The importance of getting on with a project fades if we watch the news too much. However, now more than before it is important to have routines and goals and to keep to some sort of research schedule, even if it gets broached occasionally, well, quite frequently. There is always housework. Penny is in charge of laundry; I am food and cooking chief and Penny's husband Neil is a wizard with the vacuum cleaner and wields a mean mop in the kitchen. Wednesday morning is also when Neil's philosophy group meets on Zoom. A friend's choir meets weekly on Zoom: she tells me that as all their laptops and tablets have different frequencies the noise is terrible - but fun.

Thursday: Together with Anne Greenfield, I edit the journal Restoration and Eighteenth-Century Theatre Research. We have received a series of related essays that will make up a special issue and we spend the day working through them for a first copy edit. Anne and I are old hands at long-distance editing, emailing around once a week. The worldwide web and internet can be horribly misused, but they have also hugely enabled scholarship and collaboration. I have just finished reading A Short History of Tractors in Ukrainian by Marina Lewycka, sent to me by a friend working on post-Soviet era Ukrainian literature. Undoubtedly, I have read more novels and watched more films on TV or DVD in the past year than ever before.

Friday: I have not mentioned it, but every day is significantly lightened by taking Jack for a walk. Jack is a Jack Russell-Chihuahua mix, definitely the best of both, lively, playful and cuddly and beautiful. He came from our local animal shelter and as is nearly always the case had a bit of a troubling time before he joined us.

Saturday: On every other Saturday we Zoom with our friend teaching in Boulder, Colorado. This, together with a monthly FaceTime session with a historian friend in Manchester, keeps us up to date with the difficulties and exhaustion of teaching on Zoom. Today one of my oldest friends, Gill Manning, sent me an essay she has been working on for some time on Anne Wharton's poetry. I must hurry up and send her something of mine as we always reciprocate. Now, unable to meet, it is more than usually helpful to exchange work. This is not how I imagined I would spend my golden years, but we are lucky, not trying to hold down a job, or find a job, or cope with small children desperately needing home-schooling. 
Sunday: Weather actually sunny. Garden a winter mess but there are signs of things growing. Today we sow tomato seeds: Shirley, a very tasty, heavy cropping plant; Black Krim, a purple tomato, full of anti-oxidants, and Olivade, a plum tomato and great for cooking. Sowing seeds is always a sign of hope. Now more than ever.

Here's Jack with his squeaky alligator:

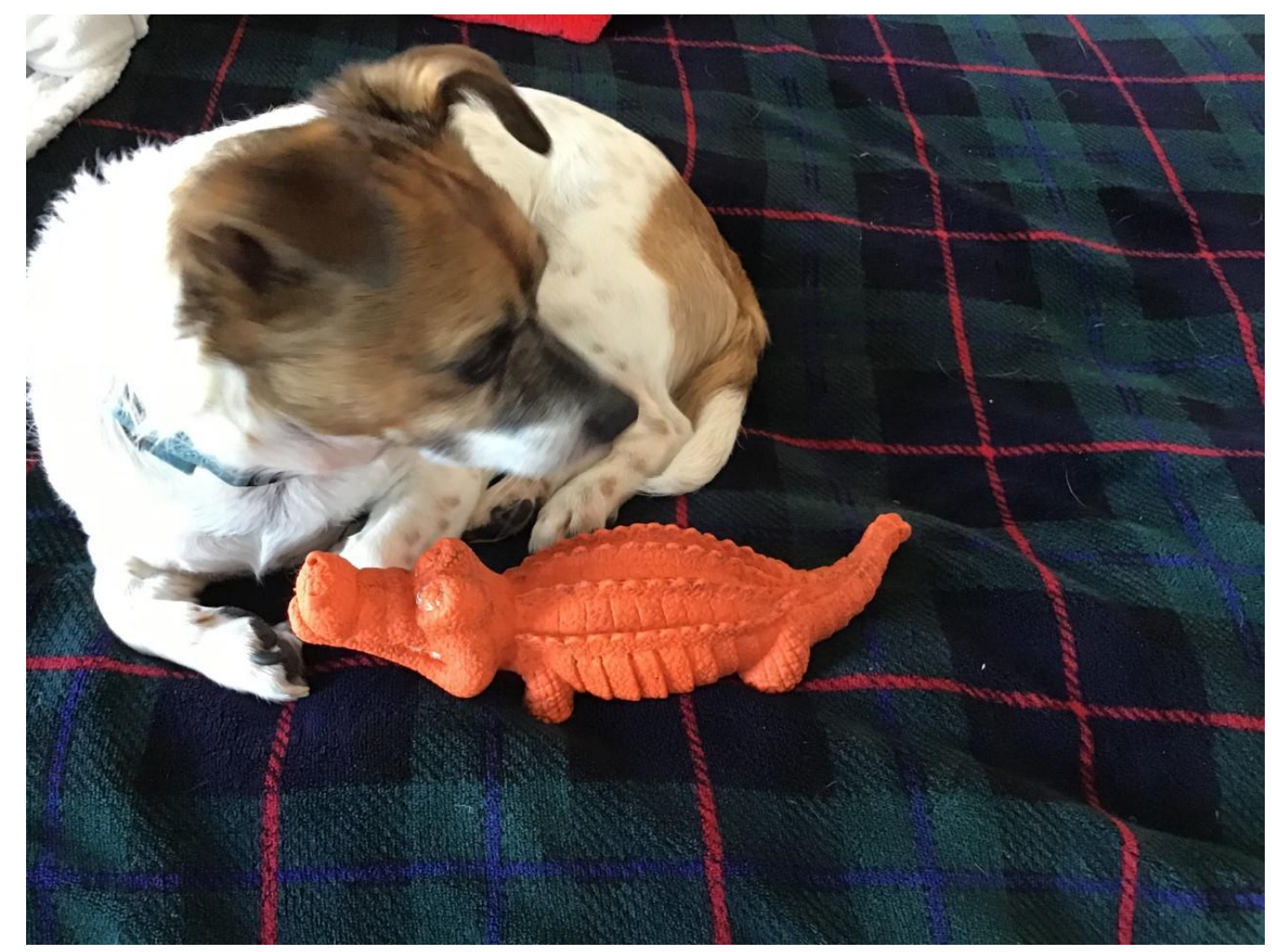

